\title{
Keberhasilan Aklimatisasi dan Pembesaran Bibit Kompot Anggrek Bulan (Phalaenopsis) Pada Beberapa Kombinasi Media Tanam
}

\section{Success of Acclimatization and Enlargement of Compote Seeds Orchid Month (Phalaenopsis) on Some Combinations of Plant Media}

\author{
Lisa Erfa", Desi Maulida, Rizka Novi Sesanti, dan Yuriansyah \\ ${ }^{1}$ Politeknik Negeri Lampung \\ *E-mail : lisaerfa@polinela.ac.id
}

\begin{abstract}
Acclimatization is a critical stage for plantlets. In new environments, plantlets can experience environmental stress. Environmental conditions such as media that do not support the acclimatization stage can cause plantlet death. This study aims to: 1) obtain the best combination of media for the successful acclimatization of the Phalaenopsis orchid plantlet; 2) Determine whether there is an interaction between the bottom of the media with the top of the pot; 3) Getting the best combination of media for the growth of Phalaenopsis orchid seedlings in the enlargement stage, and 4) Seeing whether coconut coir media can be used for acclimatization and enlargement of Phalaenopsis orchids. The study was conducted at the Lampung State Polytechnic net home from March to August 2018. Plantlet was acclimatized 4 weeks. Factorial experiments were carried out in a randomized block design. Factor A: the type of bottom media (brick / charcoal). Factor B: types of top media (sphagnum moss / fern / coconut fiber). Six treatment combinations were tried (each with 10 replications), namely: P1 (brick + moss); P2 (brick + fern); P3 (brick + coconut fiber); P4 (charcoal + moss); P5 (charcoal + fern); and P6 (charcoal + coconut fiber). Observed variables: 1) percent success of plantlets to become seedlings, 2) seed height, 3) leaf length,4) leaf width, and 5) number of leaves. The data obtained was analyzed by analysis of variance and continued with a 5\% BNJ test. The results showed: 1) Moss or fern mediacombined with brick or charcoal gave the best percentage of acclimatization of Phalaenopsis orchid plantlets (100\%); 2) There is no interaction between the top media and the bottommedia; 3) The best combination of media for the growth of Phalaenopsis orchid seeds in the enlargement stage is moss, either combined with brick or charcoal, then followed by fern (combined with brick or charcoal); and 4) Coconut coir media can be used for acclimatization and enlargement of Phalaenopsis orchid seedlings if more intensive watering is done.
\end{abstract}

Keywords: Phalaenopsis, acclimatization and seedling enlargement, media combination.

Disubmit : 08 Juni 2019; Diterima : 10 Juli 2019; Disetujui : 01 September 2019

\section{PENDAHULUAN}

Phalaenopsis (anggrek bulan) adalah salah satu genus anggrek yang memiliki daya tarik tersendiri.

Keragaman warna, bentuk dan tekstur, serta aromanya menjadikan anggrek Phalaenopsis sebagai salah satu bunga terindah (Djaafarer, 2008). Selain itu anggrek ini memiliki daya tahan bunga yang cukup panjang menjadi faktor penyebab tingginya nilai ekonomi anggrek (Aminarsi, Syaifullah, dan Yulianingsih, 1999). Phalaenopsis dikembangkan dari spesimen eksklusif yang ditujukan untuk bunga potong maupun anggrek pot yang sangat populer dan diminati. Di antara tanaman hias, budidaya anggrek Phalaenopsis sebenarnya adalah budidaya yang paling penting dan menguntungkan di Indonesia dunia (Khin et al. 2001; Hwang et al.2004). 
Permintaan anggrek terus meningkat, dan hingga kini produksinya belum bisa memenuhi permintaan pasar (Sinaga, 2014). Untuk memenuhi perdagangan anggrek di Indonesia masih bergantung pada bibit impor (Riri, 2016). Salah satu upaya yang dapat dilakukan adalah dengan memperbanyak anggrek Phalaenopsis dengan metoda Kultur in vitro. Keberhasilan perbanyakan tanaman in vitro di laboratorium sangat tergantung tahap akhir perbanyakan yaitu aklimatisasi. Aklimatisasi merupakan tahap pengadaptasian plantlet dari lingkungan in vitro ke lingkungan baru di luar botol. Tahap ini merupakan tahap yang kritis bagi plantlet dimana plantlet akan mengalami perubahan fisiologi karena faktor lingkungan yang baru. Menurut Romodhon (2017, plantlet yang dihasilkan selama kultur in vitro dapat abnormal morfologi, anatomi, dan fisiologinya. Selain itu Menurut Yusnita (2014), pada perbanyakan in vitro (dalam botol) faktor lingkungan terkontrol sedangkan di lapangan faktor lingkungan sulit terkontrol. Pada lingkungan yang baru plantlet dapat mengalami cekaman lingkungan (Yasmin, Aisyah, dan Sukma. 2018). Kondisi lingkungan yang tidak mendukung pada tahap aklimatisasi dapat menyebabkan kematian plantlet.

Salah satu faktor lingkungan yang penting diperhatikan pada tahap aklimatisasi plantlet dan pembesaran bibit anggrek adalah media tanam. Media tanam penting karena sebagai penompang tanaman, mempertahankan kelembaban, menyediakan nutrisi dan aerasi akar (Kaveriamma, 2019). Media tanam

merupakan faktor yang dapat menentukan keberhasilan aklimatisasi dan pembesaran bibit anggrek. Media tanam yang dapat digunakan untuk anggrek yaitu moss sphagnum, pakis, akar kadaka, sabut kelapa atau cocopit, arang kayu, pecahan bata, atau potongan kulit pinus. Masing-masing media mempunyai kelebihan dan kekurangan. Penggunaan media dapat dikobinasikan dengan komposisi tertentu untuk memenuhi kebutuhan anggrek akan lingkungan yang ideal bagi pertumbuhan (Anonim, 2014). Pemilihan media selain ditentukan dari harganya, mudah tidaknya media tersebut diperoleh, kondisi lingkungan, juga ditentukan oleh bagaimana pengaruhnya terhadap pertumbuhan bibit/tanaman anggrek. Umumnya media moss banyak digunakan pada anggrek Phalaenopsis. Media pakis banyak digunakan pada anggrek Dendrobium dan Phalaenopsis. Selain itu, bahan limbah tanaman yang potensi digunakan untuk media anggrek yaitu sabut kelapa. Ketiga media tersebut memiliki kelebihan dan harga yang berbeda. Untuk itu ingin dilihat bagaimana pengaruh kombinasi macam media terhadap keberhasilan aklimatisasi dan pertumbuhan bibit kompot pada tahap pembesaran.

Tujuan Penelitian penelitian ini yaitu untuk Mendapatkan kombinasi media yang paling baik bagi keberhasilan aklimatisasi plantlet anggrek Phalaenopsis. Mengetahui apakah terdapat interaksi antara media bagian bawah dengan atas pot. Mendapatkan kombinasi media yang paling baik bagi pertumbuhan bibit anggrek anggrek Phalaenopsis pada tahap pembesaran. Melihat apakah media sabut kelapa dapat digunakan untuk aklimatisasi dan pembesaran anggrek Phalaenopsis

\section{METODE PENELITIAN}

Penelitian dilaksanakan di rumah jaring Politeknik Negeri Lampung dari bulan Maret hingga Agustus 2018. Plantlet (tanaman lengkap yang dihasilkan in vitro) yang akan ditumbuhkan di luar botol/lapangan diaklimatisasikan (diadaptasikan) selama 4 minggu dari dikeluarkan. Percobaan merupakan percobaan faktorial yang dilaksanakan dalam rancangan acak kelompok (pengelompokan berdasarkan ukuran plantlet). Faktor A : macam media di bagian bawah pot (bata dan arang). Faktor B : macam media di bagian atas pot (moss sphagnum, pakis, dan sabut kelapa). Jadi ada 6 kombinasi perlakuan yang dicobakan, dan setiap kombinasi perlakuan dicobakan dengan 10 ulangan. Kombinasi perlakuan yang dicobakan yaitu: P1 (media bata + moss); P2 (media bata + pakis); P3 (media bata + sabut kelapa); P4 (media arang + moss); P5 (media arang + pakis); dan P6 (media arang + sabut kelapa). Peubah yang diamati: 1) persen keberhasilan/konversi plantlet menjadi bibit (persen bibit yang tumbuh), 2) tinggi bibit, 3) panjang daun, 4) lebar daun, dan 5) jumlah daun. Data yang diperoleh dilakukan analisis ragam dan dilanjutkan dengan uji BNJ pada taraf 5\%. 
Media sabut kelapa yang digunakan hanya berupa serat-serat halus. Media bata/arang didisikan pada pot sebanyak 1/3 pot lalu ditambahkan media moss/pakis/sabut kelapa (tergantung perlakuan) hingga $\pm 1 \mathrm{~cm}$ dari atas permukaan pot (berdiameter $15 \mathrm{~cm}$ ).

Plantlet anggrek Phalaenopsis dikeluarkan dari botol, direndam larutan fungisida $\left(2 \mathrm{~g} . \mathrm{L}^{-1}\right)$ selama 10 menit, kemudian dikering anginkan. Selanjutnya plantlet ditanamkan pada pot berdiameter $15 \mathrm{~cm}$ yang telah berisi media perlakuan sebanyak 10 tanaman per pot, kemudian di letakkan dan dipelihara di rumah jaring. Pengamatan dilakukan sejak tanaman berumur 1 minggu setelah tanam hingga 4 minggu, untuk menentukan persentase keberhasilan plantlet menjadi bibit. Selanjutnya bibit dipelihara hingga berumur 12 minggu setelah tanam.

Pemeliharaan bibit dilakukan dengan dipupuk kristallon/vitabloom diberikan 2 kali seminggu dengan cara disemprotkan 2 g. $\mathrm{L}^{-1}$, sedangkan dekastar diberikan hanya sekali saat tanam sebanyak $5 \mathrm{~g}$ per pot.

\section{HASIL DAN PEMBAHASAN}

Plantlet yang dihasilkan diaklimatisasikan pada beberapa macam kombinasi media untuk melihat pengaruh kombinasi media terhadap keberhasilan aklimatisasi plantlet (persen konversi plantlet menjadi bibit) maupun pertumbuhan bibit anggrek Phalaenopsis pada tahap pembesaran.

Hasil penelitian menunjukkan baik media moss atau pakis yang dikombinasikan dengan bata atau arang menghasilkan keberhasilan aklimatisasi (persen konversi plantlet menjadi bibit) $100 \%$ (Tabel 1). Plantlet yang diaklimatisasikan pada media sabut kelapa mengalami kematian sebanyak $15 \%$ jika dikombinasikan dengan bata, sedang yang dikombinasikan dengan arang mengalami kematian 8.4\%. Tingginya keberhasilan aklimatisasi pada media moss sesuai dengan apa yang dihasilkan Yasmin, Aisyah, dan Sukma (2018) bahwa pada media moss keberhasilan aklimatisasi anggrek Phalaenopsis mencapai 100\%.

Tabel 1. Persentase keberhasilan aklimatisasi plantlet Phalaenopsis sp. menjadi bibit

\begin{tabular}{lc}
\hline Perlakuan & Persentase Plantlet Hidup \\
\hline P1 : Bata Moss (BM) & 100 \\
P2 : Bata Pakis (BP) & 100 \\
P3 : Bata Sabut kelapa (BS) & 85 \\
P4 : Arang Moss (AM) & 100 \\
P5 : Arang Pakis (AP) & 100 \\
P6 : Arang Sabut kelapa (AS) & 91.6 \\
\hline
\end{tabular}

Matinya sebagian plantlet yang diaklimatisasikan pada media sabut kelapa diduga karena rendahnya kemampuan sabut kelapa dalam memegang air. Hal ini menyebabkan kondisi lingkungan mikro plantlet kurang mendukung untuk pertumbuhan plantlet dan menyebabkan plantlet mati. Salah satu syarat media tumbuh yang baik yaitu memiliki kemampuan mengikat air dan hara dengan baik. Faktor lingkungan yang kurang mendukung dapat menyebabkan pertumbuhan plantlet kurang baik. Menurut Romodhon (2017) faktor lingkungan (kelembaban) adalah salah satu faktor yang dapat mempengaruhi pertumbuhan anggrek. tingkat keberhasilan aklimatisasi adalah $100 \%$ pada setiap GH. Hal tersebut karena media moss memiliki kelembaban yang baik sehingga kesegaran planlet tetap terjaga. Secara umum pertumbuhan plantlet Phalaenopsis untuk menjadi bibit lebih lambat dari pertumbuhan platlet anggrek jenis lain seperti Dendrobium. Hasil analisis ragam terhadap data pengamatan pada bibit berumur 12 minggu setelah diaklimatisasi menunjukkan bahwa macam media bagian bawah pot (faktor A) tidak berpengaruh nyata terhadap pertumbuhan tinggi bibit, panjang daun, dan jumlah daun, tetapi nyata mempengaruhi lebar daun pada bibit. Macam media bagian atas (faktor B) sangat nyata berpengaruh terhadap tinggi bibit, panjang daun, lebar daun, dan jumlah daun, namun tidak terdapat interaksi antara macam media bagian atas dengan macam media bagian bawah (Tabel 2). 
Tabel 2. Hasil analisis ragam pengaruh kombinasi media terhadap petumbuhan tinggi bibit, jumlah daun, dan lebar daun.

\begin{tabular}{|c|c|c|c|c|c|}
\hline \multirow{2}{*}{$\begin{array}{l}\text { Sumber } \\
\text { Keragaman }\end{array}$} & \multicolumn{3}{|c|}{ Sumber Keragaman } & \multicolumn{2}{|c|}{ F Tabel } \\
\hline & Tinggi Bibit $(\mathrm{cm})$ & $\begin{array}{c}\text { Panjang } \\
\text { Daun }(\mathrm{cm})\end{array}$ & $\begin{array}{l}\text { Lebar Daun } \\
\quad(\mathrm{cm})\end{array}$ & Jumlah Daun & 0.05 \\
\hline Kelompok & $24,1671 * *$ & $15,7954 * *$ & $13,7273 * *$ & $7,1865 * *$ & 3.335 .64 \\
\hline Perlakuan & & & & & \\
\hline A & $0,0025 \mathrm{~ns}$ & $0,0079 \mathrm{~ns}$ & $17,5535 * *$ & $4,5750 \mathrm{~ns}$ & \\
\hline B & $60,2597 * *$ & $38,9767 * *$ & $25,2480 * *$ & $13,6577 * *$ & \\
\hline $\mathrm{AB}$ & $0,1573 \mathrm{~ns}$ & $0,1573 \mathrm{nd}$ & $0,2934 \mathrm{~ns}$ & $2,0210 \mathrm{~ns}$ & \\
\hline KK & $10,4 \%$ & $7,0 \%$ & $11.8 \%$ & $7,8 \%$ & \\
\hline
\end{tabular}

Untuk melihat perbedaan antar perlakuan dilakukan uji dengan uji beda nyata jujur (BNJ) pada taraf 5\%. Hasil uji diperoleh macam media bagian bawah (Faktor A: bata atau arang ) tidak memberikan pengaruh yang berbeda terhadap pertumbuhan lebar daun pada bibit (Tabel 3).

Hasil uji BNJ pengaruh macam media tanam bagian atas (Faktor B: Moss, pakis, atau sabut kelapa) menunjukkan: media moss memberikan hasil pertumbuhan tinggi bibit tertinggi, diikuti oleh media pakis. Media yang memberikan pertumbuhan tinggi terrendah adalah media sabut kelapa. Sedangkan terhadap pertumbuhan Panjang daun, lebar daun, dan jumlah daun, media moss menunjukkan pertumbuhan yang lebih baik dari media sabut kelapa namun tidak terdapat perbedaan hasil pertumbuhan antara media moss dengan sabut kelapa (Tabel 3).

Tabel 3. Hasil uji BNJ pengaruh perlakuan macam media terhadap pertumbuhan tinggi bibit, panjang daun, lebar daun, dan jumlah daun pada bibit umur 12 minggu setelah diaklimatisasi.

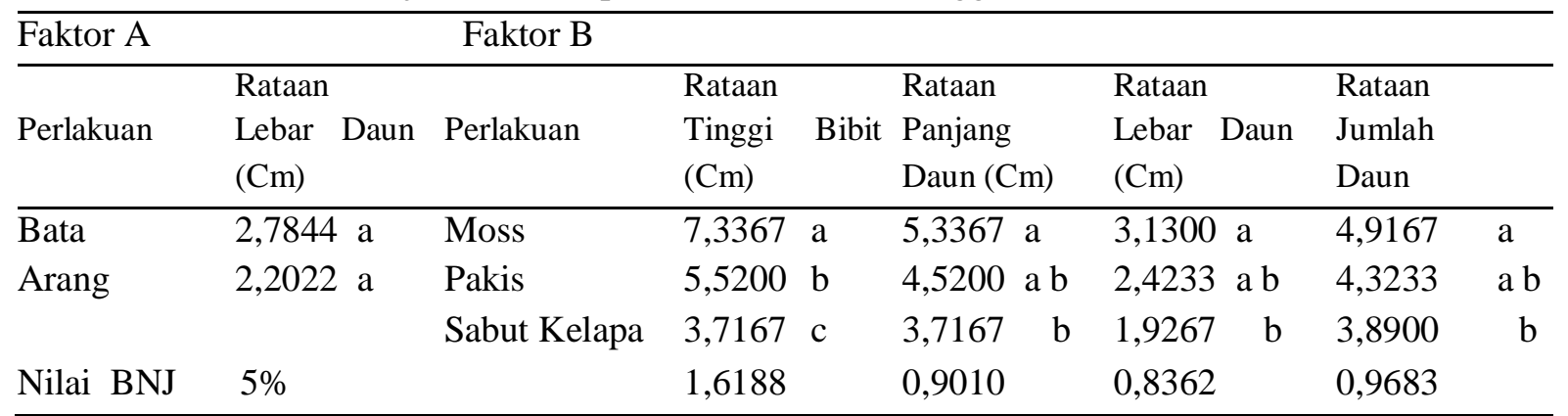

Ket : Angka rataan yang diikuti oleh huruf yang sama menunjukkan tidak berbeda nyata dengan uji BNJ pada taraf $5 \%$

Hasil uji BNJ pada taraf 5\% di atas, terlihat bahwa kombinasi media moss baik yang dikombinasikan dengan bata atau arang nyata memberikan pertumbuhan tinggi yang lebih baik dari media pakis dan sabut kelapa (Gambar 1). Demikian pula terhadap pertumbuhan panjang daun, lebar daun dan jumlah daun, kedua media tersebut (moss dan pakis) memberikan hasil pertumbuhan yang lebih baik dari media sabut kelapa.

Dikombinasikan bata ataupun arang. Dengan demikian macam media bagian atas yaitu media moss (baik dikombinasikan dengan bata ataupun arang) selain menghasilkan persen keberhasilan aklimatisasi yang tinggi (100\%), juga menghasilkan pertumbuhan paling baik. 

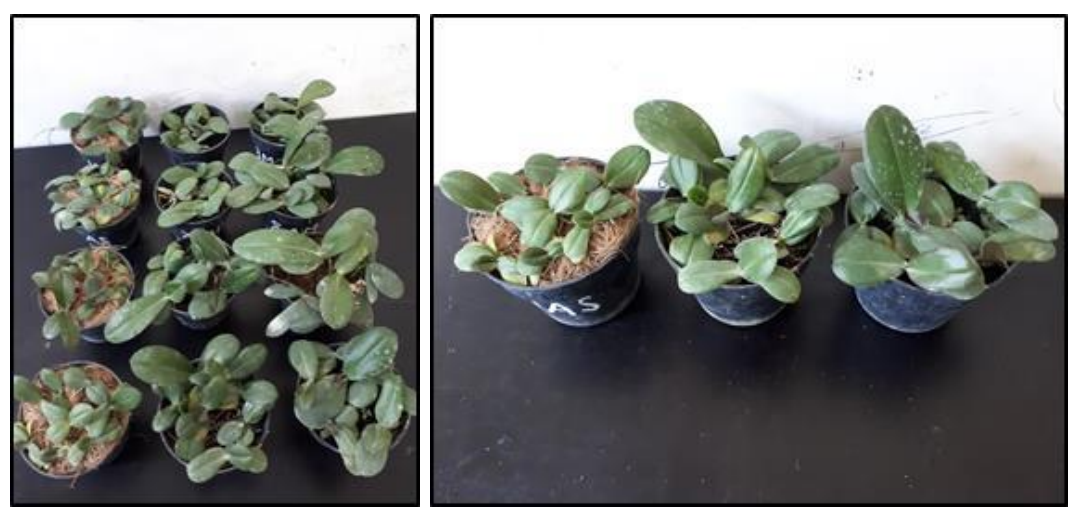

Gambar 1. Pertumbuhan bibit anggrek Phalaenopsis pada media bata/arang yang Dikombi nasikan dengan moss/pakis/sabut kelapa umur 12 minggu setelah diaklimatisasi

Lebih baiknya pertumbuhan bibit pada media moss (baik dikombinasikan dengan bata maupun arang) diduga karena media moss mempunyai kemampuan memegang air dengan cepat dan menahannya dalam waktu yang lebih lama dari media pakis dan sabut kelapa. Menurut Anonim (2014), jika dilihat dari sifatnya dalam menahan air maka secara umum media moss dapat menyimpan banyak air sedangkan media pakis dapat menyimpan air sedang. Media moss dan media pakis memiliki aerasi yang baik. Dengan demikian media moss diduga dapat menyerap, menyimpan, dan menyediakan pupuk dengan baik, maupun dapat menjaga kelembaban. Kondisi ini akan memberikan kondisi lingkungan yang baik bagi pertumbuhan bibit anggrek Phalaenopsis. Sedangkan media sabut kelapa (baik dikombinasikan dengan bata maupun arang menghasilkan pertumbuhan bibit yang kurang baik/lambat. Dengan demikian untuk menghasilkan bibit/tanaman kompot (komuniti pot) yang siap di repoting menjadi bibit individual pot atau remaja 1 memerlukan waktu yang lebih lama. Namun media pakis memungkinkan untuk digunakan pada aklimatisasi plantlet maupun pembesaran bibit bila dilihat dari tingginya persen keberhasilan aklimatisasi (85-92\%) jika dilakukan pemeliharaan khususnya penyiraman yang lebih intensif.

\section{KESIMPULAN}

Media moss atau pakis dikombinasikan dengan bata maupun arang memberikan persen keberhasilan aklimatisasi plantlet anggrek Phalaenopsis yang paling baik (100\%). Tidak terdapat interaksi antara media bagian atas dengan bagian bawah. Kombinasi media yang paling baik bagi pertumbuhan bibit anggrek Phalaenopsis pada tahap pembesaran adalah moss baik dikombinasikan dengan bata ataupun arang, kemudian diikuti oleh pakis (dikombinasikan dengan bata ataupun arang). Media sabut kelapa dapat digunakan untuk aklimatisasi dan pembesaran bibit anggrek Phalaenopsis bila dilakukan penyiraman yang lebih intensif.

\section{UCAPAN TERIMA KASIH}

Ucapan terima kasih penulis sampaikan kepada Direktorat Riset dan Pengabdian Masyarakat (DRPM) Ditjen Penguatan Riset dan Pengembangan Kementrian Ristekdikti yang telah memberikan dana hingga penelitian ini dapat terlaksana.

\section{DAFTAR PUSTAKA}

Amiarsi, D., Syaifullah, dan Yulianingsih. 1999. Komposisi TerbaikuntukLarutan Perendam Bunga Anggrek Potong Dendrobium Sonia DeepPink. J. Hort. 9(1): 45-50.

Anonim, 2014. Medium Tumbuh. http://bioscbiologi.blogspot.com/2014/03/medium-tumbuh. Html.

Djaafarer, R. 2008. Phalaenopsis spesies. Cetakan II. Penebar Swadaya. Jakarta. 96 Hal. Hwang S.J., Huh M.R., Chung J.I., Jeong B.R., 2004. Growth of Phalaenopsis in recirculating 
Ebb and Flood hydroponic system as affected by ionic strength of solution and medium composition. Acta Hort. 659, 637-645.

Kaveriamma, M.M, Rajeevan, P.K., Girija, D. Nandini, K. 2019. Sphagnum Moss as Growing Medium in

Phalaenopsis Orchid. International Journal of Current Microbiology and Applied Sciences ISSN: 23197706 Volume 8 Number 02.

Khin T.M., Chung M.Y., Chung J.D., Kim C.K., 2001. Propagation via in vitro culture of leaf tissue of Phalaenopsis seedlings. J. Kor. Soc. Hort. Sci. 42, 1-5.

Riri, A. 2016. Bisnis Anggrek Indonesia Tergantung Bibit Impor. http://www.wartaplus.com/2016/05/16/bisnis-anggrek-indonesia-tergantung- bibitimpor.html

Romodhon, S. 2017. Pengaruh Berbagai Media Tanam terhadap Aklimatisasi Anggrek Dendrobium sp.

Skripsi. Program Studi Agroteknologi Fakultas Pertanian Universitas Medan Area. Medan.

Sinaga, N.E. 2014. Peluang Terbuka Menembus Pasar Global. http://tabloidsinartani.com/content/read/peluang-terbuka-menembus-pasar-global/

Yasmin, Z. F., Aisyah, S. I., dan Sukma, D. 2018. Pembibitan (Kultur Jaringan hingga Pembesaran) Anggrek Phalaenopsis di Hasanudin Orchids, Jawa Timur. Bul. agrohorti 6 (3) : 430 - 439. https://www.researchgate.net/publication/327555806_Pembibitan_Kultur_Jaringan_hingga_Pembesar an_Anggrek_Phalaenopsis_di_Hasanudin_Orchids_Jawa_Timur/citation/download

Yusnita. 2014. Kultur Jaringan: Cara Memperbanyak Tanaman Secara Efisien. Agro Media Pustaka, Jakarta. 